\title{
STUDENT PERCEPTIONS OF THE FACTORS \\ INFIUENCING THEIR SUCCESS IN \\ FIRST-YEAR ACCOUNTING
}

LEN STEENKAMP

ROELOF BAARD

LIEZEL FRICK

\section{Introduction}

$[\mathrm{T}]$ he learner brings an accumulation of assumptions, motives, intentions, and previous knowledge that envelopes every teaching/learning situation and determines the course and quality of learning that may take place.

(Biggs, 1996:348)

Biggs's understanding of the determining influences students may have on the teaching and learning environment is supported by a variety of authors in the field of Accounting education (Byrne \& Flood, 2005; Duff, 2004; Duff, Boyle, Dunleavy \& Ferguson, 2004; Lucas \& Meyer, 2004; Ramburuth \& Mladenovic, 2004). The changed and increasingly diversified student populations in higher education across the world (Cross, 2004; Drost, 2002; Lowe \& Cook, 2003) amplify the need for Accounting lecturers to take note of their students' assumptions, motives, intentions, and previous knowledge that may influence student success (Byrne \& Flood, 2005).

Various studies provide general information on students entering the higher education system (for example, Masitsa, 2004; Mji, 2002; Pillay, 2004; Toni \& Oliver, 2004; Wößmann, 2003). A number of studies focus on Accounting students' approaches to learning (Byrne, Flood \& Willis, 2004; Duff, 2004; Lucas \& Meyer, 2004; Ramburuth \& Mladenovic, 2004), while Hermanson, Deines, Eldridge, Hermanson, Ivancevich and Williams (1996) focus on the recruitment of first-year Accounting students in the USA. Du Plessis, Müller and Prinsloo (2005), Müller, Prinsloo and Du Plessis (2007), Rowlands (1988) and Van Rensburg, Penn and Haiden (1998), focus particularly on the first-year success of Accounting students at three different South African universities. The South African-based studies investigated the causal relationships between various indicators, notably students' prior school performance, 
as possible predictors of future academic success. These studies did not consider the students' own perceptions of their chances of success at university. Gracia and Jenkins (2002:95) argue that '[i]t seems likely that there are more active and subjective forces at work in determining performance that are not captured by statistical studies'. Biggs' implied emphasis on possible student-centred factors that influence the teaching and learning environment therefore leaves room for further investigation in Accounting education in South Africa.

This study therefore aimed to investigate first-year students' perceptions of factors that influence their success in Financial Accounting at a South African university. Even though the intention of the reported results is not generalised beyond the scope of the study itself, the information may provide valuable information to first-year lecturers and the planners of foundation programmes.

\section{Orientation to the study}

Financial Accounting 188, with approximately 1,300 registered students annually, is a compulsory first-year subject for all Bachelor of Commerce (BComm) students at Stellenbosch University. Of these 1,300 students, approximately $40 \%$ to 50\% have no background in Accounting in that they did not study Accounting as a subject at secondary school. The course content covered in the first semester of the module is similar to the content covered in Accounting at secondary school, although a more conceptual approach is followed at the University. This allows students the opportunity to follow a BComm degree without having studied Accounting as a subject at secondary school. The course is presented by five lecturers to groups of 200 to 300 students per class and the language of instruction in the module is predominantly Afrikaans, with some English used in the lectures. Although Stellenbosch University is an institution that promotes Afrikaans as an academic language, approximately $40 \%$ to $50 \%$ of these students indicate each year at registration that their home language is English. Additional learning support measures are provided for many of these students through tutorials, additional beginners' group classes and peer mentoring to assist those students with no Accounting background and those who may experience language difficulties.

The throughput rate for the subject has been below 70\% for the past number of years, which is consistent with the throughput rate figures for a similar module provided by another South African university (Du Plessis et al., 2005). Over time, the lecturers teaching in the module formed their own assumptions (based on personal observations, experience and conversations) on the reasons for the relatively low throughput. These assumptions are the following:

$\square$ Nearly half of the students studying the module have no (school-based) background in Accounting, and because the complete content of secondary school Accounting is covered in the first semester, students with no background in Accounting tend to struggle with the module, especially in the first semester.

There is a lack of adequate preparation at school level in Accounting. Learners are taught how to do Accounting, but the principles of and reasons for Accounting 
are not adequately addressed or assessed. First-year students with a background in Accounting might therefore have certain misconceptions about Accounting.

$\square$ There is limited provision for English tuition in the specific faculty and some English-speaking students may experience language difficulties.

Class attendance by students is low, averaging $40 \%$ to $50 \%$ weekly.

$\square$ Students are poorly prepared for tests and exams.

The unsatisfactory success rate of first-year students in Financial Accounting prompted the relevant lecturers to consider the possible causes of student failure. An inter-disciplinary team investigated possible causes for the lack of first-year students' success in the particular module with the purpose of promoting learning and eventual student success. Killen and Fraser (2002) note possible differences in the perceptions of students and lecturers on what contributes to academic success. If these different perceptions of the factors that contribute to success or failure can be identified, it may be possible to enhance students' chances of success.

The research problem in the study was therefore formulated as: What are students' perceptions of factors that influence their success in Financial Accounting 188?

An exploratory interpretive study using a questionnaire was employed to investigate student perceptions of factors influencing their success in Financial Accounting 188. The study was conducted amongst the 2007 cohort of Financial Accounting 188 students in the second half of 2007. A response rate of $80.15 \%$ was achieved in response to a detailed questionnaire containing both quantitative and qualitative elements. The results provide valuable empirical insight into the attitudes and perceptions of first-year students in the particular module, with a focus on what students themselves perceive as factors that influence their success. This insight may facilitate a more learner-centred ethos through the development of student support systems and teaching practices based on an empirically founded notion of student needs. The results of the study are currently being used to implement changes in the Financial Accounting 188 module.

\section{Methodology}

The research aimed to give a descriptive analysis (Henning, Van Rensburg \& Smit, 2004) of the perceptions of first-year students in Financial Accounting at Stellenbosch University. Students' perceptions of factors influencing their success in Financial Accounting 188 were empirically investigated by means of questionnaires containing quantitative and qualitative elements. Babbie and Mouton (2001) propose that it is appropriate to use questionnaires in a descriptive investigation. From the results of these questionnaires, certain interpretations could be made regarding the factors that students perceived to be influencing their success in this module.

A purposive sample was drawn for the questionnaire. The sample consisted of all students registered for the particular module, Financial Accounting 188, in the second semester of 2007. Questionnaires consisting of two sections were administered to these students at a formal assessment opportunity to ensure the best possible 
response rate. The students were given the opportunity to complete the questionnaire before commencing with the test. A response rate of $80.15 \%$ (1,042 respondents) was obtained. Gay (1987) recommends a minimum sample size of $10 \%$ of the total target population for a descriptive study. The results of the study can therefore be generalised to the total target population of first-year students registered for the module in Financial Accounting at the particular university, but not beyond this parameter.

The research design and methodology used aimed to make the study replicable and therefore reliable. Bias was avoided by means of a well-planned purposive sampling strategy (students were asked to complete the questionnaire prior to a compulsory assessment opportunity) and the study of relevant and recent literature to guide the construction of the questionnaire. A questionnaire that was pilot tested and used within a previous unpublished study on first-year student perceptions served as a further basis for the questionnaire construction. These elements added to the validity of the measuring instrument.

A limitation of the study is that it focused mainly on students' own perceptions. This situation might not be a reflection of reality. We do acknowledge that student perceptions may be misleading and may furthermore not constitute all the factors that possibly influence student success. This study, however, focused on students' perceptions as a starting point to gain insight into the first-year academic experience in the particular context.

\section{Results and discussion}

\section{Factors prohibiting success}

Students were asked in open-ended questions what they perceived as hindering factors in their own performance in Financial Accounting 188, as well as possible reasons for their fellow students' lack of success in the module. The latter allowed for the possibility that students may have been more honest if they were given the chance to indicate why somebody else was not performing well.

One of the main reasons cited by respondents $(\mathrm{N}=986)$ for their own lack of success was the absence of English classes $(n=206)$. The respondents also perceived a lack of English classes as playing a notable role $(n=161)$ in hampering other students' success, as indicated in the following respondent's comment: 'Some of the terminology is difficult to convert from Afrikaans to English'.

The researchers had expected that the absence of English classes might have played a role in students' success, and therefore two Likert-type questions were posed on this matter. The results are summarised in Table 10.1. 
Table 10.1 Analysis of Likert scale responses to Afrikaans and English as teaching media

\begin{tabular}{|c|c|c|c|c|c|}
\hline $\begin{array}{l}\text { Percentage of respondents per } \\
\text { Likert scale category } \\
\text { Response category }\end{array}$ & $\begin{array}{l}\text { Disagree } \\
\text { strongly }\end{array}$ & Disagree & Agree & $\begin{array}{l}\text { Agree } \\
\text { strongly }\end{array}$ & Uncertain \\
\hline $\begin{array}{l}\text { Afrikaans as teaching language used in } \\
\text { class prevents me from performing well } \\
\text { in Fin Acc. }\end{array}$ & $51.4 \%$ & $9.1 \%$ & $10.7 \%$ & $26.1 \%$ & $2.7 \%$ \\
\hline $\begin{array}{l}\text { English classes would help me to } \\
\text { perform better in Fin Acc. }\end{array}$ & $47.4 \%$ & $4.4 \%$ & $7.9 \%$ & $37.9 \%$ & $2.4 \%$ \\
\hline
\end{tabular}

More than a third (36.8\%) of the students cited Afrikaans classes as an impediment to their success in Financial Accounting. Of these students, 15.8\% gave Afrikaans as their home language $(5.7 \%$ out of the total sample population). This seemingly incongruous finding might be explained by the fact that $56.8 \%$ of these respondents had completed their Grade 12 in either English or bilingual schools. Nearly half of the respondents (45.8\%) thought that English classes would contribute to their success in the subject. These students were predominantly English first language students (69.4\%), or Afrikaans first language students who had attended either English or bilingual schools (7.2\%). These students may therefore have been more comfortable with English lectures.

Students $(\mathrm{n}=225)$ also perceived a lack of time available for study as a perceived limiting factor to their success. Compared to the 225 respondents who cited lack of time as a factor determining their lack of success, only 16 respondents believed that other students had time management issues. In addition, 10\% of respondents indicated that their colleagues had underestimated the module, compared to only $0.7 \%$ who confessed that they themselves had underestimated the module. Fazey (1993:236) found that modularised courses were well suited to students who could plan their time according to 'both extrinsically imposed demands and their own aspirations in relation to existing skill level'. The single most important factor noted for hindering their own success in the module, was a perceived lack of time. Students may perceive a lack of time as something outside their own control, and therefore a 'legitimate' excuse. The data from this study suggests that two possible aspects of time need to be taken into account in future studies: students' own time management capabilities, as well as time allocated to the module within the framework of the programme(s) of which it forms a part.

Students may use language, and even time allocated to a module and teaching effectiveness as 'convenient' extraneous excuses for poor performance, but the data suggested that the respondents were also able to be critical of themselves and arguably showed a remarkable level of honesty by their admitting that insufficient studying $(\mathrm{n}=109)$ and laziness $(\mathrm{n}=77)$ were the main factors hindering success:

... my work ethics ...

I'm lazy, LAZY I tell you. Need to work more. 
Only a small number $(n=23)$ ascribed poor performance to their poor class attendance. When students were asked why other students failed, more than two-thirds of the total response group for this question $(\mathrm{N}=1,007)$ indicated that other students' lack of success was due to their own inactions, i.e. not studying enough $(\mathrm{n}=354)$ and not attending class $(n=323)$. The respondents clearly seemed to be more critical of their colleagues, as only 109 and 23 respondents respectively cited these as main factors determining their own lack of success. These results confirm the findings of Duff et al. (2004) that conscientiousness has an influence on academic performance.

The main student-related factors cited as limiting success were a lack of motivation; lack of self-discipline, concentration and interest in the subject; not asking for help; not perceiving the subject to be important; having a mental block or negative attitude; and making unnecessary errors. Transport issues were also noted as a possible limiting factor.

In summary, the main factors - according to the respondents - leading to failure to perform well in Financial Accounting 188 were poor class attendance and insufficient studying (factors within students' control), a lack of English classes (outside their control) and a lack of time (which could be either under their control or not).

\section{Factors promoting success}

Students were asked which factors promoted their success, in contrast to the previous section. The main factors that respondents $(\mathrm{N}=902)$ perceived to be helpful in their own success in Financial Accounting 188 were hard work $(n=269)$, practising the work $(n=261)$, and attending class $(n=140)$. Respondents attributed having had Accounting at school as a contributing factor in approximately a tenth $(n=100)$ of the responses. Self-motivation and innate ability were also deemed to be important factors contributing to respondents' success $(n=90)$. These perceived influences on success support the results put forth by Duff et al. (2004), who postulated an approach to learning as a determining factor in academic success.

Many students mentioned additional sources of help, such as attending tutorials (attendance is not compulsory) $(\mathrm{n}=95)$, making use of mentors $(\mathrm{n}=81)$, going to extra classes $(n=75)$, and asking peers for help $(n=36)$. The following responses attest to the perceived importance of individual commitment, as well as to the additional support systems implemented to help students:

The extra classes are amazing; it helps a lot to do the work yourself.

I think there is so much help so far already. Students just have to make use of it.

I feel lecturers have done everything for us already.

Studying hard, attending class and mentor and writing down what's done in class.

I try to work at it myself and I attend all my lectures and I get help when I need it. 
In all, 286 of the respondents indicated that additional outside help was beneficial to their Financial Accounting studies.

\section{Class attendance}

It was proposed at the initiation of the study that class attendance played a role in students' success. Evidence of poor class attendance was assumed to hinder success and attending class assumedly promoted success. With this in mind, two questions were asked on class attendance. Students were again asked which factors prevented them from attending class and, in a separate question, which factors prevented other students from attending class. The responses to these two open-ended questions are discussed in the remainder of this section.

The main reason cited for not attending class was that the respondents had to study for tests $(n=138)$. This might be indicative of poor time management by students. Related to this factor was the perceived heavy workload imposed by other subjects $(n=58)$, which could indicate that the other subjects were seen to be more important, or at least that they were more urgent. Virtually no respondents allowed for the possibility that other students might also have had to study for tests, but a small number allowed that the workload of other subjects might have played a role in their success $(\mathrm{n}=15)$.

Respondents mentioned Afrikaans classes as a reason for not attending class since they did not understand Afrikaans $(n=130)$. The lack of English classes was also rated highly as a possible reason why other students may not have attended classes $(\mathrm{n}=165)$, as the following response indicates:

They don't understand Afrikaans, therefore just give up and many think they'll manage on their own. See lectures as a waste of time.

This finding corresponds to the earlier finding where respondents emphasised language as a perceived factor influencing their success.

A dislike of early morning classes $(n=89)$, tiredness $(n=85)$, the demands of student life $(\mathrm{n}=28)$, and laziness $(\mathrm{n}=80)$ were also commonly noted as reasons for non-attendance, which are all factors within students' own locus of control - as this response indicates:

I struggle waking up in the morning in the winter due to the weather and little self-discipline.

Again, the respondents were more critical of their colleagues. Laziness was provided as a reason by approximately one-fifth $(n=200)$ of the respondents $(\mathrm{N}=975)$. Interestingly, fewer students blamed morning classes $(\mathrm{n}=30)$ as the reason for their fellow students' lack of attendance than for their own poor attendance $(n=89)$. Illness or other ad hoc events were cited by 59 students as reasons for own nonattendance.

A notable number of respondents felt that class attendance was not important $(n=33)$, that classes were 'boring' $(n=45)$, or that they understood the work and 
therefore did not need to attend class $(n=37)$. A significant proportion of respondents' wrote that other students did not attend classes because these students thought they understood the work $(n=162)$, had Accounting at school and therefore did not need to attend classes $(n=157)$, or found the classes boring $(n=142)$ or not important $(n=65)$. Few students directly indicated in this open-ended question that previous school exposure to Accounting prevented them from attending class. This was borne out by the results in a Likert scale question where only $16 \%$ of the respondents $(9 \%$ of the total) to the question replied that they felt they did not need to attend classes because they had taken Accounting at school. One could argue that students who had completed Accounting as a school subject may find classes 'boring' or unnecessary, but this is speculative in the case of the particular study. Bergin (1983) does, however, indicate that students who had Accounting as a school subject find that they do not need to study hard, especially during the first components of university Accounting modules, which may - in turn - result in poor study habits that are hard to break later on in the programme. Rowlands (1988) furthermore warns that these potentially good students may lose interest in Accounting as a result of this lack of intellectual stimulation at the onset of their studies and consequently be lost to the discipline afterwards.

Table 10.2 provides a comparison between the most prevalent reasons cited by the respondents for their own and other students' non-attendance.

Table 10.2 Reasons cited for lack of class attendance

\begin{tabular}{|c|c|c|c|c|}
\hline \multirow{2}{*}{ Perceived factors preventing class attendance } & \multicolumn{2}{|c|}{ Other students } & \multicolumn{2}{|c|}{ Self } \\
\hline & $\%$ & $\mathbf{n}$ & $\%$ & $\mathbf{N}$ \\
\hline \multicolumn{5}{|l|}{ Reasons for lack of class attendance } \\
\hline Have to study for tests & $0.1 \%$ & 1 & $16.3 \%$ & 138 \\
\hline Do not understand Afrikaans & $16.9 \%$ & 165 & $15.3 \%$ & 130 \\
\hline Early morning class $-8: 00$ & $3.1 \%$ & 30 & $10.5 \%$ & 89 \\
\hline \multicolumn{5}{|l|}{ Reasons for other students' lack of class attendance } \\
\hline Lazy & $20.5 \%$ & 200 & $9.4 \%$ & 80 \\
\hline Do not understand Afrikaans & $16.9 \%$ & 165 & $15.3 \%$ & 130 \\
\hline Think they understand the work & $16.6 \%$ & 162 & $4.4 \%$ & 37 \\
\hline
\end{tabular}

\section{Discussion and conclusion}

This chapter has given consideration to the factors that students perceive as influencing their success in Financial Accounting 188 at Stellenbosch University, South Africa. This study was prompted by a traditionally relatively low throughput rate for the 
subject. The research was conducted by means of a questionnaire distributed among students, in which a response rate in excess of $80 \%$ was achieved.

Based on past experience, lecturers assumed that the throughput rate was negatively influenced by a number of specific factors. These factors will now be considered in terms of students' own perceptions.

\section{No background in Accounting}

As Accounting at school is not a prerequisite for taking Financial Accounting, this was considered by lecturers to be a possible impediment to students' success. However, students did not believe that it played a significant role in their success, with only one-tenth of students indicating that it hindered other students' success and only half of that number believing that it influenced their own success negatively. It was the perception of approximately one-tenth of the respondents that Accounting as a school subject aided their success. Indirectly it might play a role, as approximately onesixth of the respondents felt that students did not attend class as they had studied Accounting at school and it was therefore not necessary for them to attend class.

\section{Limited English tuition}

No Financial Accounting 188 classes are presented only in English at the University. Some use is made however in lectures, to attempt to accommodate English students. Lecturers were of the opinion that English students might struggle to understand the work, as subject specific terms were presented in a second or third language. Students concurred with this view, with a substantial number of the respondents indicating that a lack of English classes hindered their success.

\section{Low class attendance}

Traditional wisdom would have it that class attendance is important to being successful in Financial Accounting and students' failure to take notice of regular exhortations to attend class contributes to their eventual failure of the subject. Students seemed to realise this, as nearly a third of the respondents thought that other students' lack of success was at least partly due to poor class attendance. They, however, seemed to think that this played a limited role in hindering their own performance.

\section{Lack of adequate preparation at school level}

The Financial Accounting lecturers felt that students might receive inadequate preparation at school level, thereby not preparing them for the rigours of Financial Accounting at university level. Yet not one of students cited this as a possible reason for failure in the open-ended questions. This does not, however, serve as proof that it may not be a factor in student success. Students may not be in a position to assess their preparation for further study at school objectively. 


\section{Poor preparation for tests and examinations}

The low throughput rate was at least partially ascribed by the lecturers to the fact that students did not prepare well enough for tests and examinations. Students seemed to agree with this perception, with one-third believing that other students did not study enough for Financial Accounting and nearly half of the respondents indicating that they themselves did not study enough for the subject. Hard work, regular practice and own effort were cited by more than two-thirds of the respondents as factors that aided their success.

\section{Recommendations}

A number of recommendations can be made to address the different factors that students perceive as affecting their performance negatively.

The language factor could be addressed by implementing English classes. However, this is an institutional issue which does not lie within the addressable ambit of the department itself. This problem could partially be addressed by the use of mentor groups where specific tutor groups have an English mentor who would understand the issues faced by these students.

In terms of poor class attendance, the only factors that could possibly be addressed by lecturers and/or the University would be the lack of English classes and, to a lesser degree, that students think they understand the work and therefore do not need to attend the classes. English classes may be implemented as a possible solution to the first problem. Regular assessment opportunities, for example, on a bi-weekly basis, might help students to realise that they do not understand the work as well as they might think (since this notion is contradicted by students' actual performance and consequently a low throughput rate). Such regular assessments would also be effective in motivating students to stay up to date and to study throughout for Financial Accounting.

It is also recommended that the findings from this study be shared with students at the start of the academic year. This might further motivate them to take the subject seriously and to attend classes, as these findings are based on the opinions of their peers and not just another lecturer prescribing what students should be doing. It can therefore be stated that students implicitly understand that their success in Financial Accounting 188 (at least partly) lies in their own hands and depends on their own efforts.

\section{References}

Babbie, E. \& Mouton, J. 2001. The practice of social research. South African Edition. Cape Town: Oxford University Press.

Biggs, J. 1996. Enhancing teaching through constructive alignment. Higher Education, 32:347-364.

Bergin, J.L. 1983. The effect of previous accounting study on student performance in the first college-level financial accounting course. Issues in Accounting Education, 1:19-28.

Byrne, M. \& Flood, B. 2005. A study of accounting students' motives, expectations and preparedness for higher education. Journal of Further and Higher Education, 29(2):1 11 -124. 
Byrne, M., Flood, B. \& Willis, P. 2004. Validation of the Approaches and Study Skills Inventory for Students (ASSIST) using accounting students in the USA and Ireland: A research note. Accounting Education, 13(4):449-459.

Cross, M. 2004. Institutionalising campus diversity in South African higher education: Review of diversity scholarship and diversity education. Higher Education, 47:387-410.

Drost, A. 2002. The dynamics of occupational choice: Theory and evidence. Labour, 16(2):201-233.

Duff, A. 2004. Understanding academic performance and progression of first-year accounting and business economics undergraduates: The role of approaches to learning and prior academic achievement. Accounting Education, 13(4):409-430.

Duff, A., Boyle, E., Dunleavy, K. \& Ferguson, J. 2004. The relationship between personality, approach to learning and academic performance. Personality and Individual Differences, 36:1907-1920.

Du Plessis, A., Müller, H. \& Prinsloo, P. 2005. Determining the profile of the successful first-year accounting student. South African Journal of Higher Education, 19(4):684-698.

Fazey, D.M.A. 1993. Self-assessment as a generic skill for enterprising students: The learning process. Assessment and Evaluation in Higher Education, 18(3):235-250.

Gay, L.R. 1987. Educational research. Competencies for analysis and application. 3rd ed. Colombus: Merrill Publishing Company.

Gracia, L. \& Jenkins, E. 2002. An exploration of student failure on an undergraduate accounting programme of study. Accounting Education, 11 (1):93-107.

Hermanson, R.H., Deines, D.S., Eldridge, C., Hermanson, D.R., Ivancevich, S.H. \& Williams, D.Z. 1996. Strategies for recruiting the best and brightest students into accounting. Journal of Accounting Education, 14(3):347-365.

Henning, E., Van Rensburg, W. \& Smit, B. 2004. Finding your way in qualitative research. Pretoria: Van Schaik Publishers.

Killen, R. \& Fraser, W.J. 2002. Success and failure in tertiary studies: Perceptions of students and lecturers. Paper presented at the Annual conference of the South African Association of Educators. Pretoria, South Africa. 26-29 September.

Lowe, H. \& Cook, A. 2003. Mind the gap: Are students prepared for higher education? Journal of Further and Higher Education, 27(1):53-76.

Lucas, U. \& Meyer, J.H.F. 2004. Supporting student awareness: Understanding student preconceptions of their subject matter within introductory courses. Innovations in Education and Teaching International, 44(4):459-47 1.

Masitsa, G. 2004. Four critical causes of under-achievement in township secondary schools. Acta Academica, 36(1):213-245.

Mji, A. 2002. What influences students to university education? Insights from the horse's mouth. South African Journal of Higher Education, 16(2):166-1 76.

Müller, H., Prinsloo, P. \& Du Plessis, A. 2007. Validating the profile of a successful first-year accounting student. Meditari Accountancy Research, 15(1):19-33.

Pillay, J. 2004. Experiences of learners from informal settlements. South African Journal of Education, 24(1):5-9.

Ramburuth, P. \& Mladenovic, R. 2004. Exploring the relationship between students' orientations to learning, the structure of students' learning outcomes and subsequent academic performance. Accounting Education, 13(4):207-527.

Rowlands, J.E. 1988. The effect of secondary school accounting study on school performance in the first year university financial accounting course. De Ratione, 2(2):17-21.

Toni, M.N. \& Olivier, M.A.J. 2004. Academic identities of black female first-year students. South African Journal of Education, 24(3):194-199. 
Van Rensburg, P., Penn, G. \& Haiden, M. 1998. A note on the effect of secondary school accounting study on university accounting performance. South African Journal of Accounting Research, 12(1):93-98.

Wößmann, L. 2003. Schooling resources, educational institutions and student performance: The international evidence. Oxford Bulletin of Economics and Statistics, 65(2):1 17-170. 